\title{
Interest rates and convergence across Italian regions
}

Sheila Dow

Alberto Montagnoli

Oreste Napolitano

Stirling Economics Discussion Paper 2009-13

May 2009

Online at http://www.economics.stir.ac.uk 


\title{
Interest rates and convergence across Italian regions
}

\author{
Sheila Dow ${ }^{\dagger}$, Alberto Montagnoli ${ }^{\ddagger}$ and Oreste Napolitano ${ }^{\S}$
}

May 2009

\begin{abstract}
The purpose of this paper is to investigate the evidence for economic convergence across Italian regions using trends in interest rate spreads and premia as indicators of regional credit conditions. Our results indicate the presence of persistent interest rate differentials, and thus an absence of convergence across the twenty political regions, but we observe a high degree of convergence within the four macroeconomic areas. On the other hand we find evidence of a strong level of homogeneity in credit conditions within each of the four macroeconomic regions.
\end{abstract}

JEL Classification Codes: C23, E43, R11 and R15.

Keywords: interest rates, unit root, panel data, convergence, Italy.

$\dagger$ Division of Economics, University of Stirling, s.c.dow@stir.ac.uk;

† Division of Economics, University of Stirling, alberto.montagnoli@stir.ac.uk;

$\S$. Department of Economic Studies, University of Naples Parthenope, napolitano@uniparthenope.it 


\section{Introduction}

The dualistic nature of the Italian economy is a well-known phenomenon which has been analysed and debated in many studies. ${ }^{1}$ Moreover, there is a vast amount of literature on the issue of whether or not there is convergence across economies or regions over time. These studies have mainly focused their attention on the behaviour of different economies over the business cycle in order to uncover the presence of real asymmetries between regions or nations. ${ }^{2}$ The conventional dichotomy involving long-run and short-run policy analysis has only recently been re-examined. ${ }^{3}$ Similarly it is only recently that the positive view about Italian regional development and convergence has been developed. ${ }^{4}$

The underlying thinking of all these studies is based, directly or indirectly, on Mundell's (1961) optimal currency area theory. He argued that, if economic shocks have differential consequences for different economies, i.e. if they do not impact on these economies homogeneously, then these economies would not together constitute an optimal currency area in the absence of appropriate adjustment mechanisms. Thus, we would expect such economies not to converge. It follows that, for an economy which is not an optimal currency area, any macroeconomic policy decision taken by central government would also be sub-optimal since it would not fit all, and could contribute to divergence.

Later, however, Mundell (1973) focused his attention on the benefits of monetary union as itself providing the basis for adjustment to asymmetric shocks. A common currency and integrated financial markets would provide the means for adjustment, at least to temporary asymmetric shocks, by means of capital flows, but longer-lasting shocks would still need more price and wage adjustment. We would therefore expect greater convergence within a common currency area, other things being equal. Some studies have addressed this issue by identifying differences between saving and investment in each economy as indicators of the power of capital flows to cushion economies from short-term shocks (see Bayoumi and Rose, 1993).

\footnotetext{
${ }^{1}$ See for example Iammarino et al. (2004), Guerrieri and Iammarino (2003), Evangelista et al. (2002) and Mauro (2004).

${ }^{2}$ See for example Angeloni et al. (2003), Aris (2003), De Grauwe and Mongelli (2005).

${ }^{3}$ See for example Topel (1999) and Aricó (2003).

${ }^{4}$ See Barro \& Xavier Sala-I-Martin (1991) and Mauro (2004).
} 
The capacity for financial account imbalances within a currency area would therefore be expected to ease adjustment to shocks.

Regional economic theory has challenged this notion that integrated financial markets tend to promote economic convergence. According to Dow (1982, 199), Dow and Montagnoli (2007), Martin (1989), Martin and Minns (1995) and MacKay and Molyneux (1996), the spatial structure of an economy matters. This can be summarized in three points: i) information imperfections and transaction costs increase with distance from markets; ii) lack of local credit market means that SMEs face funding problems; iii) spatial differences in supply and demand may be mutually reinforcing. These points are mainly drawn on Dow's $(1990,1992)$ relative liquidity preference theory of the relationship between the spatial evolution of a national banking system and the process of uneven regional development. Dow's theory suggests that the free movement of capital and financial integration will lead to spatial centralization of the financial system, which in turn will lead to uneven economic development between the centre and periphery of the space economy. Contrary to the neoclassical view, an integrated financial system will encourage a net outflow of capital from the periphery to the core, and these flows in turn will fuel the process of uneven economic development between the core and the periphery (Martin and Minns, 1995).

Testing this hypothesis has frequently proved difficult given the lack of available of regional data on the distribution of bank credit, and finance more generally. Nevertheless, a few studies have attempted to analyse data on regional money flows along these lines, for Australia and Canada (Porteous, 1995), for Brazil (Amado, 1997), for Spain (Rodriguez Fuentes, 2005) and for various British regions (see Dow, 1992, Dow and Montagnoli, 2007, Martin, 1989, Martin and Minns, 1995, and MacKay and Molyneux, 1996). The common view running through this strand of literature seems to be, first, that over-centralization of the financial system disadvantages peripheral regions, and, second, a local financial infrastructure characterized by local and regional based banks is better for those regions (Martin and Minns, 1995). These points are summarized as follows in MacKay and Molyneux (1996: 763): 'it seems that spatial diversity of financial structures will continue to persist as long as economic diversity exists. The shocking suspicion that flows of capital may add to rather than limit the regional inequality does not disappear.' 
This study tries to contribute some empirical evidence to inform this debate. We analyse the question of whether Italy, as an optimal currency area, has reached convergence in the credit sector. Hence in this paper we take a novel approach to regional credit markets, facilitated by Italian data availability, by focusing on regional interest rates. Rather than investigating net capital account imbalances for each region, we investigate regional interest rate differentials as an alternative indicator of imbalances. In particular, high demand for investment finance relative to supply in any region is taken to be reflected in high long-term rates relative to short-term rates. Similarly, tighter credit conditions in any region are taken to be reflected in higher loan rates relative to deposit rates. If capital is mobile within the national economy, regional convergence would be associated with a process of moving towards uniformity of rates following any shock, while divergence would be reflected in persistent regional rate differentials.

We take Italy as our case study, a country for which data on regional interest rates are available. To investigate whether there are synergies across the twenty Italian regions we look in particular at the behaviour of interest rates spreads and premia. We define the interest rate spread as the difference between the long-term and short-term rates; the interest rate premium is defined as the difference between the interest rate on loans and the interest rate on deposits. We take these series as alternative indicators of regional credit conditions. We employ panel data unit root tests to examine the dynamic of interest rate spreads and premia across Italian regions.

The remainder of the paper is organized as follows; the next section presents the data, Section 3 reports the results and policy implications, and Section 4 concludes.

\section{Data and econometric methodology}

Our dataset is comprised of quarterly time-series on short-term and long-term interest rates on loans and on interest rates on banks' deposits. All data were obtained from the Regional Bulletin published by the Bank of Italy. The dataset covers all twenty Italian regions and the full sample period under investigation is 1998Q1-2007Q7, providing 40 observations per region, with a cross-section of twenty. 
Table 1 presents the summary statistics for the two series for each political and economic region. ${ }^{5}$ There is a large heterogeneity in the mean and standard deviation across the various regions for both variables. An important feature emerges; there is a clear dichotomy between the North and the South of the country: the premia, i.e. the cost of borrowing for the southern regions exhibit values above the national average.

The benchmark model that defines whether a region is converging can be written as:

$$
\left(i_{i t}-i_{i t}^{*}\right)=\alpha_{i} d_{m, t}+\varphi_{i}\left(i_{i t-1}-i_{i t-1}^{*}\right)+\varepsilon_{i t}
$$

where $i_{i t}$ is a measure of regional credit conditions (measured either by the interest rate spread or interest rate premium in region $i) . i_{t}^{*}$ is the corresponding value at national level, $d_{m, t}$ is a vector of deterministic variables which influence credit conditions, and $\varepsilon_{i t}$ is an iid error.

Equation (1) can be rewritten and reparametrized as an autoregressive process of order $n$ :

$$
\Delta x_{i t}=\alpha_{i} d_{m t}+\rho x_{t-1}+\sum_{i=1}^{n} \beta_{i} x_{i t-1}+\varepsilon_{i t}
$$

where $x_{i t}=\left(i_{i t}-i_{i t}^{*}\right), \rho=\sum_{i=1}^{n} \phi_{i}-1$, and $\sum_{i=1}^{n} \varphi_{i}=\varphi$.

$\rho$ in Equation (2), corresponding to $\phi$ in Equation (1), is the parameter of interest. If its value is $|\phi|<1$ then Equation (1) is said not to have a unit root. In this case the interest rate is stable and any economic shock, to which a region is subject, will over time be absorbed by the system, reducing regional interest rate differentials again. Moreover, if $\alpha \neq 0$ the process is stable around a non-zero mean. On the contrary,

\footnotetext{
${ }^{5}$ Italy has 20 political regions; the economic regions reflect the different economic structures across Italy. They are defined as: North-West (Liguria, Piemonte, Valle d'Aosta, Lombardia), North-East (Friuli Venezia Giulia, Trentino Alto Adige, Veneto), Centre (Abruzzo, Emilia Romagna, Lazio, Marche, Molise, Toscana, Umbria), South and Islands (Basilicata, Calabria, Campania, Puglia, Sardegna, Sicilia). In the remainder of the text, the terms 'economic regions' and 'macro regions/areas' are used interchangeably.
} 
if $|\phi|=1$, the time series follows a random walk and any economic shock will be permanently incorporated in the series. Finally, if $|\phi|>1$, the process is explosive.

We can therefore use unit root tests to investigate whether the parameter of interest in Equation (2) is statistically different from one. If it is statistically different from one, we cannot reject the hypothesis that the regions are converging.

Given that our time dimension comprises ten years, univariate unit root tests may suffer from low power in such a small sample. Here, alongside the traditional test, we therefore consider more powerful panel approaches to examine the degree of non-stationarity across regional interest rates differentials. The four tests implemented are presented below.

First, we utilise panel unit root tests which assume that the residual error term in the panel regression is $\sigma^{2} \mathrm{I}$, where $\mathrm{I}$ is the identity matrix. This is consistent with the idea that the cross-sections are not affected by common shocks, an approach adopted by Culver and Papell (1997) when examining aggregate inflation data.

We start our analysis by assuming that $\rho$ in Equation (2), i.e. the persistence parameter, is common across regions. Following Levin, Lin and Chu (2002) (LLC hereafter), we use Equation (2) to test the null hypothesis that the common slope has a unit root $\left(H_{0}: \rho=0\right)$ against the alternative that all series $x_{i}$ are stationary.

The limit of the LLC test is the assumption of homogeneity of the persistence parameter $(\rho)$; thus, we employ the tests of Im, Pesaran and Shin (2003) (hereafter IPS). This test utilises a panel version of the Dickey Fuller model, which can be specified as follows:

$$
\Delta x_{i t}=\alpha_{i} d_{m, t}+\rho_{i} x_{i t-1}+\sum_{i=1}^{N} \beta_{i} x_{i t-1}+\varepsilon_{i t}
$$

The IPS test has a null hypothesis that all regional interest rate rates differentials are random walks with drift:

$$
H_{0}: \rho_{1}=\rho_{2}=\ldots=\rho_{i}=\rho=0
$$

against a heterogeneous alternative hypothesis: 
$H_{1}: \phi_{1}<0, \ldots, \phi_{N_{1}}<0, \quad N_{1} \leq N$

The test statistic, $Z_{\tilde{t} b a r}$ is based on an average of the individual cross-section ADF test statistics. In particular,

$Z_{\tilde{t} b a r}=\sqrt{N}\left\{\tilde{t} b a r_{N T}-E\left(\widetilde{t}_{T}\right)\right\} / \sqrt{\operatorname{Var}\left(\widetilde{t}_{T}\right)} \quad \Rightarrow \mathrm{N}(0,1)$

where $\mathrm{N}(0,1)$ is the standard normal distribution. Also $\widetilde{t}_{b a r_{N T}}=1 / N \sum_{t=1}^{N} \widetilde{t}_{i T}$ and $\widetilde{t}_{i T}$ are the standard cross section unit root test statistics.

The third test we implement uses the Breitung method; the basic approach is similar to the LLC test, but it modifies it in two ways. First the exogenous component is not removed when the standardized proxies are computed. Then the proxies are transformed and detrended. ${ }^{6}$

Finally, we implement the Maddala and Wu (1999) test. They show that under the null-hypothesis of unit root for all the cross-section $\mathrm{N}$, the following asymptotic result holds true:

$-2 \sum_{j=1}^{N} \log \left(\pi_{j}\right) \rightarrow \chi_{2 N}^{2}$

where $\pi_{j}$ is the p-value for the unit root test for any cross-section $j$.

\section{Empirical results}

In this section we present the empirical results for all four tests and discuss the implications of these regarding convergence across the Italian regions.

The four unit root tests presented above are implemented using three different cross sections. We first test for the presence of a unit root between region $i$ and the national value, first for the interest rate premium, then for the spread. These are

\footnotetext{
${ }^{6}$ For the full specification, see Breitung (2000)
} 
presented in Table $2 \mathrm{a}$ and $4 \mathrm{a}$, respectively. In all four cases we cannot reject the hypothesis that the data have a unit root, and thus that the regions do not converge.

Of course it is impossible within a panel framework to investigate whether this is the result of just some of the regions diverging or rather a generalised phenomenon; hence we repeat the experiment using various cross sections. Still considering the same two differentials, Tables $2 \mathrm{~b}-2 \mathrm{e}$ show the results where the cross section is given by the number of regions in the macro area. This should give us an idea whether some of the macro areas converge to the national value. But again the results point in the direction of the presence of a unit root in both the interest rate spread and the premium, so that we do not find convergence among the larger, macro regions either.

Finally we test whether this persistence is present across regions within macro areas. The results are set out in Tables $3 a-3 d$ for interest rate premia, and $5 a-5 d$ for interest rate spreads. In all cases except one (the North-east), we can reject the unit root hypothesis at the usual statistical level of confidence. Hence there is a clear indication that interest rate premia and spreads do not tend to converge with the national value, but rather they follow the dynamics of the relevant macro areas.

The persistence of wide spreads can be explained by a number of systemic problems that, for instance, can be applied to the majority of the southern Italian regions. These could include a lack of adequate competition in the region's banking sector, the apparent market risk, bank unreliability, diseconomies of scale due to the small (regional) markets, high fixed and operating costs and the lack of development of regional economies and their financial markets. ${ }^{7}$

The results we have reported above provide persuasive evidence of persistent interest rate differentials within Italy, challenging the notion that national capital markets are fully integrated.

Our evidence of persistent regional differentials implies that any asymmetric shock will not be absorbed by capital flows within Italy, but will rather be reflected in persistent regional differences in credit conditions. The further implication is that any change in monetary policy, as one such shock, does not have the same impact across Italy. This is consistent with evidence for Spain and the UK (e.g. Rodriguez-Fuentes, 2005; Dow and Montagnoli, 2007).

\footnotetext{
${ }^{7}$ See Bodo and Sestito (1989), Mauro and Podrecca (1994), Paci and Pigliaru (1995), Carmeci and Mauro (2002).
} 
The policy implications of our research are that, for regional economic convergence in Italy, measures are required to ease credit conditions in the lowergrowth regions. Further study of the factors which have encouraged convergence within the macro regions would serve to illuminate how such an outcome might be achieved for the nation as a whole. At the same time, since monetary policy is likely to have divergent effects on different regions, regional policy is required, even if only to offset the effects of national macroeconomic policy.

Finally, if there are interest rate differentials within nations, we should expect differentials also within larger economic areas. Yet EMU was expected to bring about interest rate convergence. Indeed, as de Grauwe (2003: 136) puts it: '[T]he interest rate convergence criterion [for EMU entry] is redundant. As soon as countries are expected to satisfy the other criteria, market forces make sure that the interest rates quickly converge'. But to the extent that national interest rate data suggest convergence at the national level, our evidence suggests that this masks divergence within each national economy.

\section{Conclusion}

This paper has investigated the issue of convergence across Italian regions. Using a series of panel unit root test we have shown that Italy is characterized by four macroareas which follow different dynamics.

The large interest rate spreads and premia which are evident over the Italian regions, in our opinion, have not been sufficiently investigated. Since the Italian regions operate under a single currency area, theory suggests that there are enough conditions for the convergence of interest rates towards an average national level (net of single region risk). However, the widespread perception, confirmed by our results, is that interest rate convergence did not occur in Italy, either before or after membership of EMU.

In particular, our empirical results based on panel data suggest that the twenty regions do not move together, but convergence is found within, but not across, the four macro regions: North-East, North-West, Central and South. Despite the theoretical consensus about the factors that can contribute to regional differences in 
spreads and premia, there is a lack of literature analysing the convergence towards macro regions.

\section{References}

Amado, A (1997) Disparate Regional Development in Brazil: A Monetary Production Approach. Aldershot: Ashgate.

Angeloni I., Kashuap, A. and Mojon, B. (2003) Monetary Policy Transmission in the Euro Area, Cambridge: Cambridge University Press.

Aricó F. (2003) 'Growth and unemployment: Towards a theoretical integration', Journal of Economic Surveys 17(3): 419-55.

Artis, M.J. (2003) 'Is there a European business cycle?', CES-ifo Working Papers, No 1053.

Barro, R.J. and Sala-I-Martin, X. (1991) 'Convergence across states and regions', Brookings Paper on Economic Activity 1: 107-58.

Bayoumi T. and Rose, A. (1993) 'Domestic savings and intra-national capital flows', European Economic Review, 37 (6), pp. 1197-1202.

Bodo, G. and Sestito, P. (1989) 'Disoccupazione e Dualismo Territoriale'. Temi di Discussione del Servizio Studi Banca d’Italia, 123 (August).

Breitung, J. (2000) 'The Local Power of Some Unit Root Tests for Panel Data', in B. Baltagi (ed.), Advances in Econometrics, Vol. 15: Nonstationary Panels, Panel Cointegration, and Dynamic Panels, Amsterdam: JAI Press, pp. 161-78.

Carmeci, G. and Mauro, L. (2002) 'The convergence of the Italian regions and unemployment: Theory and evidence', Journal of Regional Science 42(3): 509-32.

Culver, S. E., and Papell, D. H. (1997) 'Is there a unit root in the inflation rate?

Evidence from sequential break and panel data models', Journal of Applied Econometrics, 12: 436-44.

De Grauwe, P. and Mongelli, F. (2005) 'Endogeneities of Optimum Currency Areas. What Brings Countries Sharing a Single Currency Closer Together?', ECB Working Paper No. 468.

Dow, S. C. (1982) 'The Regional Composition of the Money Multiplier Process', Scottish Journal of Political Economy, 29(1): 22-44. 
Dow, S. C. (1992) 'The Regional Financial Sector: A Scottish Case Study', Regional Studies, 26 (7), 619-31.

Dow, S.C. (1999) 'Stages of Banking Development and the Spatial Development of Financial Systems', in R. Martin (ed.), Money and the Space Economy, Wiley, pp. 3148.

Dow, S.C. and Montagnoli, A. (2007) 'The Regional Transmission of UK Monetary Policy', Regional Studies 41(6): 797-808.

Evangelista R., Iammarino S., Mastrostefano V. and Silvani A., (2002) 'Looking for regional systems of innovation. Evidence from the Italian innovation survey', Regional Studies 36(2): 173-86.

Guerrieri P. and Iammarino, S. (2003) 'The Dynamics of Export Specialisation in the Regions of the Italian Mezzogiorno: Persistence and Change', SPRU Electronic Working Paper Series, no. 105.

Iammarino S., Jona-Lasinio, C. and Mantegazza, S. (2004) 'Labour productivity, ICT and regions. The revival of Italian "dualism"?', SPRU Electronic Working Paper Series, no. 127.

Im, K. S., Pesaran, M. H. and Shin, Y. (2003) 'Testing for Unit Roots in Heterogeneous Panels', Journal of Econometrics 115: 53-74.

Levin, A., Lin, C. F. and Chu, C. (2002) 'Unit Root Tests in Panel Data: Asymptotic and Finite-Sample Properties', Journal of Econometrics 108: 1-24.

MacKay, R. R. and Molyneux, P. (1996) 'Bank Credit and the regions: A comparison within Europe’, Regional Studies, 30(8): 757-63.

Maddala, G. S. and Wu, S. (1999) 'A Comparative Study of Unit Root Tests with Panel Data and A New Simple Test', Oxford Bulletin of Economics and Statistics 61: 631-52.

Martin, R. (1989) 'The Growth and Geographical Autonomy of Venture capitalism in The United Kingdom', Regional Studies, 23: 389-403.

Martin, R., and Minns, R. (1995) 'Undermining the Finanical Basis of Regions: The Spatial Structure and Implications of the UK Pension Fund System', Regional Studies, 29(2): 125-44.

Mauro, L. and Podrecca, E. (1994) 'The case of Italian regions: Convergence or dualism', Economics Notes 3: 447-68.

Mauro, L. (2004) 'The macroeconomics of Italy: a regional perspective', Journal of Policy Modelling 26 (8-9): 927-44.

Mundell, R. (1961) 'A Theory of Optimum Currency Areas', The American Economic Review 51(4): 509-17. 
Mundell, R (1973) 'Uncommon Arguments for Common Currencies', in H.G. Johnson and A. Swoboda (eds), The Economics of Common Currencies, London: George Allen \& Unwin Ltd.

Paci, R. and Pigliaru, F. (1995) 'Differenziali di Crescita tra le Regioni Italiane: un'analisi cross-section', Rivista di Politica Economica, 85: 3-34.

Porteous, D. J. (1995) The Geography of Finance. Aldershot: Avebury.

Rodriguez Fuentes, C. (2005) Regional Monetary Policy. London: Routledge.

Topel, R. (1999) 'Labor Markets and Economic Growth', in O. Ashenfelter and D. Card (eds), Handbook of Labor Economics. Amsterdan: Elsevier, pp. 2943-3029. 
Table 1. Descriptive statistics

\begin{tabular}{|c|c|c|c|c|c|c|}
\hline & \multicolumn{3}{|c|}{ Interest rate spread } & \multicolumn{3}{c|}{ Interest rate premium } \\
\hline & Mean & $\begin{array}{c}\text { Std } \\
\text { Deviation }\end{array}$ & $\begin{array}{c}\text { Correl } \\
\left(\mathbf{r}_{\mathbf{i}} \mathbf{r}_{\mathbf{N}}\right)\end{array}$ & Mean & $\begin{array}{c}\text { Std } \\
\text { Deviation }\end{array}$ & $\begin{array}{c}\text { Correl } \\
\left(\mathbf{r}_{\mathbf{i}} \mathbf{r}_{\mathbf{N}}\right)\end{array}$ \\
\hline Political Region & & & & & & \\
\hline Abruzzi & -2.23 & 0.77 & 0.25 & 6.01 & 0.47 & 0.44 \\
\hline Basilicata & -2.68 & 0.89 & -0.37 & 6.73 & 0.75 & -0.16 \\
\hline Calabria & -3.46 & 1.06 & 0.04 & 7.82 & 0.84 & 0.00 \\
\hline Campania & -2.81 & 0.82 & 0.13 & 6.83 & 0.34 & 0.07 \\
\hline Emilia Romagna & -1.53 & 0.51 & 0.02 & 4.55 & 0.44 & 0.15 \\
\hline Friuli Ven.Giu & -2.03 & 0.68 & -0.48 & 5.07 & 0.57 & -0.47 \\
\hline Lazio & -1.97 & 0.85 & -0.15 & 4.80 & 0.68 & -0.38 \\
\hline Liguria & -2.35 & 0.82 & 0.15 & 5.95 & 0.53 & -0.10 \\
\hline Lombardia & -1.18 & 0.66 & 0.04 & 4.16 & 0.57 & -0.18 \\
\hline Marche & -1.59 & 0.55 & 0.02 & 4.69 & 0.59 & -0.15 \\
\hline Molise & -3.37 & 0.65 & -0.21 & 7.15 & 0.50 & -0.11 \\
\hline Piemonte & -1.90 & 0.89 & 0.23 & 5.06 & 0.64 & -0.09 \\
\hline Puglia & -2.82 & 0.79 & 0.07 & 6.71 & 0.56 & -0.16 \\
\hline Sardegna & -2.49 & 0.91 & -0.48 & 6.29 & 0.78 & -0.03 \\
\hline Sicilia & -3.02 & 0.65 & -0.27 & 6.85 & 0.78 & -0.13 \\
\hline Toscana & -1.78 & 0.57 & -0.08 & 4.95 & 0.43 & 0.07 \\
\hline Trentino Alto Adige & -1.19 & 0.40 & -0.19 & 4.37 & 0.79 & 0.07 \\
\hline Umbria & -2.37 & 0.61 & -0.16 & 5.88 & 0.51 & 0.03 \\
\hline Val d'Aosta & -2.51 & 0.87 & -0.20 & 6.01 & 0.71 & -0.19 \\
\hline Veneto & -1.76 & 0.50 & 0.30 & 5.16 & 0.36 & 0.18 \\
\hline & & & & & & \\
\hline Economic Region & & & & & & \\
\hline North-West & -2.03 & 0.74 & -0.006 & 5.21 & 0.52 & 0.77 \\
\hline North-East & -1.61 & 0.40 & -0.11 & 4.87 & 0.42 & 0.90 \\
\hline Centre & -1.92 & 0.57 & -0.05 & 5.34 & 0.51 & -0.05 \\
\hline South & -2.95 & 0.65 & -0.01 & 6.92 & 0.54 & 0.94 \\
\hline National & -3.19 & 1.21 & -- & 6.70 & 1.28 & -- \\
\hline & & & & & & \\
\hline & & & & & \\
\hline
\end{tabular}


Table 2a. Premium (all regions - National)

\begin{tabular}{|l|c|c|}
\hline & Individual effects & $\begin{array}{c}\text { Individual effects } \\
\text { and individual } \\
\text { linear trends }\end{array}$ \\
\hline Levin, Lin \& Chu t* & -0.56 & 0.32 \\
\hline Breitung t-stat & & -0.50 \\
\hline Im, Pesaran and Shin W-stat & -0.26 & 0.95 \\
\hline ADF - Fisher Chi-square & 30.09 & 36.62 \\
\hline
\end{tabular}

Notes: Null: Unit root; Newey-West bandwidth selection using Bartlett kernel; Probabilities for Fisher tests are computed using an asymptotic Chi-square distribution. All other tests assume asymptotic normality. *,**, and *** indicate significance at the $10 \%, 5 \%$, and $1 \%$ level, respectively.

Table 2b. Premium (North-East - National)

\begin{tabular}{|l|c|c|}
\hline & Individual effects & $\begin{array}{c}\text { Individual effects } \\
\text { and individual } \\
\text { linear trends }\end{array}$ \\
\hline Levin, Lin \& Chu t* & -0.14 & 1.36 \\
\hline Breitung t-stat & & -1.07 \\
\hline Im, Pesaran and Shin W-stat & -0.16 & -0.74 \\
\hline ADF - Fisher Chi-square & 4.60 & 11.19 * \\
\hline
\end{tabular}

Notes: See Table $2 \mathrm{a}$

Table 2c. Premium (North-West - National)

\begin{tabular}{|l|c|c|}
\hline & Individual effects & $\begin{array}{c}\text { Individual effects } \\
\text { and individual } \\
\text { linear trends }\end{array}$ \\
\hline Levin, Lin \& Chu t* & 0.58 & 0.09 \\
\hline Breitung t-stat & & 0.38 \\
\hline Im, Pesaran and Shin W-stat & 0.66 & 1.59 \\
\hline ADF - Fisher Chi-square & 3.47 & 1.77 \\
\hline
\end{tabular}

Notes: See Table $2 \mathrm{a}$

Table 2d. Premium (Central - National)

\begin{tabular}{|l|c|c|}
\hline & Individual effects & $\begin{array}{c}\text { Individual effects } \\
\text { and individual } \\
\text { linear trends }\end{array}$ \\
\hline Levin, Lin \& Chu t* & -0.45 & -0.24 \\
\hline Breitung t-stat & & -0.02 \\
\hline Im, Pesaran and Shin W-stat & -0.26 & 1.59 \\
\hline ADF - Fisher Chi-square & 10.90 & 4.55 \\
\hline
\end{tabular}

Notes: See Table 2a

Table 2e. Premium (South - National)

\begin{tabular}{|l|c|c|}
\hline & Individual effects & $\begin{array}{c}\text { Individual effects } \\
\text { and individual } \\
\text { linear trends }\end{array}$ \\
\hline Levin, Lin \& Chu t* & -0.86 & -0.32 \\
\hline Breitung t-stat & & -0.71 \\
\hline Im, Pesaran and Shin W-stat & -0.61 & -0.63 \\
\hline ADF - Fisher Chi-square & 11.12 & 19.11 * \\
\hline
\end{tabular}

Notes: See Table 2a 
Table 3a. Premium North-East

\begin{tabular}{|l|c|c|}
\hline & Individual effects & $\begin{array}{c}\text { Individual effects } \\
\text { and individual } \\
\text { linear trends }\end{array}$ \\
\hline Levin, Lin \& Chu t* & -1.22 & -0.06 \\
\hline Breitung t-stat & -0.98 & -0.85 \\
\hline Im, Pesaran and Shin W-stat & 7.88 & 0.26 \\
\hline ADF - Fisher Chi-square & & 4.01 \\
\hline
\end{tabular}

Notes: See Table 2a

Table 3b. Premium North-West

\begin{tabular}{|l|c|c|}
\hline & Individual effects & $\begin{array}{c}\text { Individual effects } \\
\text { and individual } \\
\text { linear trends }\end{array}$ \\
\hline Levin, Lin \& Chu t* & $-2.85^{\star \star \star}$ & $-3.23^{\star \star \star}$ \\
\hline Breitung t-stat & & $-2.59^{\star \star \star}$ \\
\hline Im, Pesaran and Shin W-stat & $-3.30^{\star \star \star}$ & $-2.55^{\star \star \star}$ \\
\hline ADF - Fisher Chi-square & $25.65^{\star \star \star}$ & $19.56^{\star \star \star}$ \\
\hline
\end{tabular}

Notes: See Table 2a

Table 3c. Premium Central

\begin{tabular}{|l|c|c|}
\hline & Individual effects & $\begin{array}{c}\text { Individual effects } \\
\text { and individual } \\
\text { linear trends }\end{array}$ \\
\hline Levin, Lin \& Chu t* & $-2.16^{\star \star \star}$ & $-3.64^{\star \star \star}$ \\
\hline Breitung t-stat & & $-1.99^{\star \star \star}$ \\
\hline Im, Pesaran and Shin W-stat & $-2.58^{\star \star *}$ & $-2.97^{\star \star *}$ \\
\hline ADF - Fisher Chi-square & $23.09^{\star \star *}$ & $33.19 * \star *$ \\
\hline
\end{tabular}

Notes: See Table 2a

Table 3d. Premium South

\begin{tabular}{|l|c|c|}
\hline & Individual effects & $\begin{array}{c}\text { Individual effects } \\
\text { and individual } \\
\text { linear trends }\end{array}$ \\
\hline Levin, Lin \& Chu t* & $-3.44^{\star \star \star}$ & $-3.54^{\star \star \star}$ \\
\hline Breitung t-stat & $-3.62^{\star \star \star}$ & $-3.21^{\star \star \star}$ \\
\hline Im, Pesaran and Shin W-stat & $33.83^{\star \star *}$ & $-3.24^{\star \star \star}$ \\
\hline ADF - Fisher Chi-square & $29.26^{\star \star \star}$ \\
\hline
\end{tabular}

Notes: See Table 2a 
Table 4a. Spread (all regions - National)

\begin{tabular}{|l|c|c|}
\hline & Individual effects & $\begin{array}{l}\text { Individual effects } \\
\text { and individual } \\
\text { linear trends }\end{array}$ \\
\hline Levin, Lin \& Chu t* & -0.89 & -0.06 \\
\hline Breitung t-stat & & -1.65 ** \\
\hline Im, Pesaran and Shin W-stat & $-1.33^{*}$ & 1.39 \\
\hline ADF - Fisher Chi-square & 35.76 & 25.72 \\
\hline
\end{tabular}

Notes: See Table 2a

Table 4b. Spread (North-East - National)

\begin{tabular}{|l|c|c|}
\hline & Individual effects & $\begin{array}{l}\text { Individual effects } \\
\text { and individual } \\
\text { linear trends }\end{array}$ \\
\hline Levin, Lin \& Chu t* & -0.35 & 0.65 \\
\hline Breitung t-stat & & -0.61 \\
\hline Im, Pesaran and Shin W-stat & -0.37 & 1.34 \\
\hline ADF - Fisher Chi-square & 5.26 & 1.39 \\
\hline
\end{tabular}

Notes: See Table 2a

Table 4c. Spread (North-West - National)

\begin{tabular}{|l|c|c|}
\hline & Individual effects & $\begin{array}{l}\text { Individual effects } \\
\text { and individual } \\
\text { linear trends }\end{array}$ \\
\hline Levin, Lin \& Chu t* & -0.26 & -0.37 \\
\hline Breitung t-stat & & -0.39 \\
\hline Im, Pesaran and Shin W-stat & -0.29 & 0.89 \\
\hline ADF - Fisher Chi-square & 6.53 & 3.11 \\
\hline
\end{tabular}

Notes: See Table 2a

Table 4d. Spread (Central - National)

\begin{tabular}{|l|c|c|}
\hline & Individual effects & $\begin{array}{l}\text { Individual effects } \\
\text { and individual } \\
\text { linear trends }\end{array}$ \\
\hline Levin, Lin \& Chu t* & -0.01 & 0.11 \\
\hline Breitung t-stat & & -0.44 \\
\hline Im, Pesaran and Shin W-stat & -0.76 & 1.52 \\
\hline ADF - Fisher Chi-square & 13.28 & 5.00 \\
\hline
\end{tabular}

Notes: See Table 2a

Table 4e. Spread (South - National)

\begin{tabular}{|l|c|c|}
\hline & Individual effects & $\begin{array}{l}\text { Individual effects } \\
\text { and individual } \\
\text { linear trends }\end{array}$ \\
\hline Levin, Lin \& Chu t* & $-1.33^{*}$ & -0.48 \\
\hline Breitung t-stat & & $-2.05 * *$ \\
\hline Im, Pesaran and Shin W-stat & -1.14 & -0.70 \\
\hline ADF - Fisher Chi-square & 14.08 & 16.23 \\
\hline
\end{tabular}

Notes: See Table 2a 
Table 5a. Spread North-East

\begin{tabular}{|l|r|r|}
\hline & Individual effects & $\begin{array}{l}\text { Individual effects } \\
\text { and individual } \\
\text { linear trends }\end{array}$ \\
\hline Levin, Lin \& Chu t* & $-2.98^{\star \star \star}$ & $-2.42^{\star \star \star}$ \\
\hline Breitung t-stat & & $-3.75^{\star \star \star}$ \\
\hline Im, Pesaran and Shin W-stat & $-3.83^{\star \star \star}$ & $-3.17^{\star \star \star}$ \\
\hline ADF - Fisher Chi-square & $25.84^{\star \star \star}$ & $20.34^{\star \star \star}$ \\
\hline
\end{tabular}

Notes: See Table 2a

Table 5b. Spread North-West

\begin{tabular}{|l|r|r|}
\hline & Individual effects & $\begin{array}{l}\text { Individual effects } \\
\text { and individual } \\
\text { linear trends }\end{array}$ \\
\hline Levin, Lin \& Chu t* & $-6.51^{\star \star \star}$ & $-5.74^{\star \star \star}$ \\
\hline Breitung t-stat & & $-3.67^{\star \star \star}$ \\
\hline Im, Pesaran and Shin W-stat & $-6.35^{\star \star \star}$ & $-5.08^{\star \star \star}$ \\
\hline ADF - Fisher Chi-square & $54.02^{\star \star \star}$ & $39.04^{\star \star \star}$ \\
\hline
\end{tabular}

Notes: See Table 2a

Table 5c. Spread Central

\begin{tabular}{|l|r|r|}
\hline & Individual effects & $\begin{array}{l}\text { Individual effects } \\
\text { and individual } \\
\text { linear trends }\end{array}$ \\
\hline Levin, Lin \& Chu t* & $-5.49^{\star \star \star}$ & $-4.57^{\star \star \star}$ \\
\hline Breitung t-stat & & $-4.79^{* \star \star}$ \\
\hline Im, Pesaran and Shin W-stat & $-6.19^{\star \star \star}$ & $-4.83^{\star \star \star}$ \\
\hline ADF - Fisher Chi-square & $64.21^{\star \star \star}$ & $46.54 * \star$ \\
\hline
\end{tabular}

Notes: See Table 2a

Table 5d. Spread South

\begin{tabular}{|l|r|r|}
\hline & Individual effects & $\begin{array}{l}\text { Individual effects } \\
\text { and individual } \\
\text { linear trends }\end{array}$ \\
\hline Levin, Lin \& Chu t* & $-6.03^{\star \star \star}$ & $-6.10^{\star \star \star}$ \\
\hline Breitung t-stat & & $-5.34^{\star \star \star}$ \\
\hline Im, Pesaran and Shin W-stat & $-5.38^{\star * \star}$ & $-4.98^{\star \star \star}$ \\
\hline ADF - Fisher Chi-square & $50.55^{\star \star *}$ & $44.29^{\star \star \star}$ \\
\hline
\end{tabular}

Notes: See Table 2a 